\title{
GEOCHEMICAL FRACTION, MOBILITY AND BIOAVAILABILITY OF LEAD IN UNSATURATED SOIL OF YOGYAKARTA CITY, INDONESIA
}

\author{
Saw Aung Zaw Aye ${ }^{* 1}$, Heru Hendrayana ${ }^{1}$, Doni Prakasa Eka Putra ${ }^{1}$, and Tsutomo Sato ${ }^{2}$ \\ ${ }^{1}$ Geological Engineering Department, Faculty of Engineering, Gadjah Mada University, Yogyakarta, Indonesia \\ ${ }^{2}$ Laboratory of Environmental Geology, Faculty of Engineering, Hokkaido University, Kita 13 Nishi 8, Kita-Ku, \\ Sapporo 060-8628, Japan
}

\begin{abstract}
Lead $(\mathrm{Pb})$ is one of common heavy metals found in the soil of urban environment. In Yogyakarta City, Indonesia, lead content in the soil was already reported by some researchers, however all of the report were only reveals the distribution of lead concentration in the soil. Therefore, this research paper aims to understand the geochemical fraction lead in the soil of Yogyakarta City and assess the mobility and bioavailability of lead release to the environment. The soil sampling location is selected on Kotagede District, representing the oldest urban area of Yogyakarta city. A shallow bore hole was drill until about $7 \mathrm{~m}$ below the surface and soil/sediments were sampled for each $1 \mathrm{~m}$ depth started from the surface. Six steps of sequential extraction procedures were carried out to assess the geochemical fraction of $\mathrm{Pb}$ for each of soil samples. The sequential extraction shows that the highest amount of $\mathrm{Pb}$ in the soil of Yogyakarta City is found in amorphous iron oxide, crystalline iron oxide and non residual fraction form of $\mathrm{Pb}$. Based on the results of geochemical fraction, the mobility factor of lead can be calculated and reveals low mobility factor range from 0.4 to 3.3 $\%$. The mobility of lead is decreased from the surface to the deeper soil, on the other hand the bioavailability of $\mathrm{Pb}$ calculated from exchangeable and carbonate fraction is also show low risk of bioavailability. Therefore, it can be concluded that although $\mathrm{Pb}$
\end{abstract}

\footnotetext{
${ }^{*}$ Corresponding author: S.A.Z. AYE, Geological Engineering Department, Faculty of Engineering, Gadjah Mada University. Jl. Grafika 2 Yogyakarta 55281, Indonesia. E-mail: sawthataw2@gmail.com
}

concentration is high in non-residual fraction, $\mathrm{Pb}$ is in low risk condition due to its poor mobility and bioavailability. But, concern on lead contamination should be considered because if the concentration of $\mathrm{Pb}$ is enriched over the adsorption capacity of iron oxide, it can easily release to the environment and can impact to human in the future.

Keywords: Yogyakarta city, Lead, Sequential extraction, Geochemical fraction

\section{Introduction}

Heavy metal pollution is a persistent problem in many urban cities in the world. Millions of people living in and around urban centers are exposed to an unnatural and unhealthy environment which may cause a serious threat for the human health as well as for the environment (Herath et al., 2013). Heavy metals are one of the most serious pollutants in the environment due to their toxicity, persistence and bio-accumulation problems (Manta et al., 2009 and Moore et al., 2009) by rapidly increasing production, consumption and other human and animal activities of the urban society (Kanmani and Gandhimathi, 2012). In urban soils, $\mathrm{Pb}$ is one of common heavy metals that have been shown to be very useful tracers of environmental pollution. There are a number of sources of lead in our environment. Major sources of lead exposure include lead in paint, gasoline, lead mining, smelting, sewage sludge, and shooting range. Lead exposure attributable to automo- 
bile air emissions was a major exposure source (Alloway, 2013).

As for humans, poisoning with $\mathrm{Pb}$ is a major environmental and public hazard, especially for infants and young children. $\mathrm{Pb}$ enters the body mainly by skin contact and inhalation, and is metabolized in the liver. Typical symptoms of $\mathrm{Pb}$ poisoning include general fatigue, tremor, headache, vomiting, seizures, blue-black lead line on gingival tissue, and colic. $\mathrm{Pb}$ also interferes with hemoglobin synthesis, and severely damages kidney functions. It affects the viability of the fetus and its development (Bradl, 2005). In order to estimate effects and potential risks associated with elevated heavy metal concentrations that result from anthropogenic activities, the fraction of total metals that is bioavailable must be identified. Sequential extraction provides information on the partitioning of metals which can be useful in the understanding of mobility and bioavailability (Kumar et al., 2011).

Yogyakarta City is located in the central part of Java Island. In the 1930's, Yogyakarta was just a small town in the interior of Java with a population of approximately 60.000 inhabitants (Baiquni, 1994). In the last two decades, urbanization has transformed the structures of Yogyakarta City and it grows beyond its administrative boundary with about one million inhabitants. Until now, settlement pattern was shifting to many direction defined by main road networks and service centers and growing hand in hand with new business centres, education and tourism centres without proper infrastructures (Putra, 2007). Yogyakarta city is the capital of Yogyakarta Special Province, situated in Central Java, Indonesia. The city is located only about $30 \mathrm{~km}$ from the Merapi Volcano, and about $40 \mathrm{~km}$ from the coast of the Indian Ocean. The peak of the volcano reaches the elevation of $2911 \mathrm{~m}$ above sea level (Karnawati et al., 2006). Kotagede district, the south eastern part of Yogyakarta city, approximately covers 27 ha and is located about $141 \mathrm{~m}$ above the mean sea level. Most of the area is widely covered by settlement. The area was established as the Capital of Mataram Sultanate in 16th century and it was the oldest place, and renowned with silver artwork in Yogyakarta city. Since the establishment of Kotagede as the capital of Mataram, the traditional silver, gold, copper industries began to develop. The consequences of urban growth can be occurred the impacts of human activities. There are many home industries like silver, leather and batik in Yogyakarta city, especially in the Kota Gede district (Wilopo et al., 2010). The numbers of vehicles and the roads on this city is increased during the 2000 up to now. As a result, lead concentration in top soil increased by anthropogenic activity with regard to the degree of traffic density in urban area of Yogyakarta City (Budianta, 2001). Therefore, the study was conducted to determine the geochemical fraction, mobility and also the bioavailability of $\mathrm{Pb}$ in soil/sediment of Yogyakarta City.

\section{Materials and Methods}

\subsection{Sample collection}

Soil samples for $\mathrm{Pb}$ analysis were collected by using hand auger drilling from surface to a $7 \mathrm{~m}$ depth and packed in zip lock plastic bags.

\subsection{Sample preparation}

The collected soil samples were air dried at a room temperature. The stones, gravel and coarse plant roots or residues were removed to obtain a homogenous sample. After that, the soil samples were crushed and sieved through a $1 \mathrm{~mm}$ opening mesh and stored in plastic bags prior to chemical analysis. The mineralogical composition of the soil samples was analyzed using an X-ray diffractometer (XRD), while the chemical composition was determined using an X-ray fluorescence spectrometer.

\subsection{Sequential extraction experiments}

Sequential extraction provides information of different chemical fractions which can be useful to understand operationally defined phases. Numerous fraction techniques have been used for sequential extraction of heavy metals in soil. The sequential extraction of trace elements in this study was carried out as methods developed by Tessier et al. (1979). Eight soil samples 
were used for sequential extraction in the laboratory. Six steps of sequential extraction procedures conducted in this study were as follows:

1. Exchangeable fraction $\left(F_{1}\right) ; 0.2$ gram of soil was mixed with $1 \mathrm{M} \mathrm{MgCl}_{2}(1.6 \mathrm{~mL})$ shaking for $2 \mathrm{hr}$ at room temperature in 150 $\mathrm{rpm}$. After extraction, the filtrate was collected and diluted to $8 \mathrm{~mL}$ for analysis.

2. Carbonate fraction $\left(F_{2}\right)$; the residual from $\left(F_{1}\right)$ was mixed with $1 \mathrm{M}$ sodium acetate (NaOAc) (1.6 mL), adjusted to $\mathrm{pH} 5.0$ with the reagent-grade acetic acid (HOAc) and shaken for $24 \mathrm{hr}$ at room temperature. The filtrate was collected after extraction and diluted to $4.8 \mathrm{ml}$ for analysis.

3. Amorphous iron oxide fraction $\left(F_{3}\right)$; the residue from $\left(F_{2}\right)$ was mixed with $0.1 \mathrm{M}$ $\mathrm{NH}_{2} \mathrm{OH} . \mathrm{HCl}$ and $0.1 \mathrm{M} \mathrm{HNO}_{3}(8 \mathrm{~mL})$ by shaking in $30 \mathrm{~min}$ at room temperature. The filtrate was diluted to $6 \mathrm{ml}$ for analysis.

4. Crystalline iron oxide fraction $\left(F_{4}\right)$; the residue from $\left(F_{3}\right)$ was mixed with $0.2 \mathrm{M}$ Amonium oxalete $(8 \mathrm{~mL})$ by shaking $3 \mathrm{hr}$ at room temperature. The filtrate was diluted to $6 \mathrm{ml}$ for analysis.

5. Organic fraction $\left(F_{5}\right)$; the residue from $\left(F_{4}\right)$ is mixed with $0.7 \mathrm{M} \mathrm{NaOCl}(12.5 \mathrm{ml})$, and shakes $40 \mathrm{~min}$ at $115^{\circ} \mathrm{C}$. After shaking, the mixture was left for $30 \mathrm{~min}$ to cool. The filtrate was diluted to $50 \mathrm{ml}$ prior to analysis.

6. Residual fraction $\left(F_{6}\right)$; the residue from $\left(F_{5}\right)$ is mixed with $1 \mathrm{M} \mathrm{HCl}(6.6 \mathrm{ml})$, and shakes 2 hours at room temperature. After shaking, the filtrate was diluted to $50 \mathrm{ml}$ ready for analysis.

\section{Results and Discussion}

\subsection{Mineralogy and chemical composition of soil}

Results of XRD analysis of the soil samples showed that plagioclase was mainly present in the bulk soil sample, while kaolinite, plagioclase and illite were present in clay-size fractions of the soil samples (Figure 1). Chemical compositions of the soil samples as shown in
Table 1 are $\mathrm{SiO}_{2}, \mathrm{Al}_{2} \mathrm{O}_{3}, \mathrm{Fe}_{2} \mathrm{O}_{3}$ with percentages of 58.50 to $51.1 \mathrm{wt} . \%$ (average $56.64 \mathrm{wt} . \%$ ), 21.20 to $17.00 \mathrm{wt} . \%$ (average $19.64 \mathrm{wt} . \%$ ) and 9.66 to 6.39 wt.\% (average $7.75 \mathrm{wt} \%$ ), respectively as high content of major elements in the soil. The other major elements such as $\mathrm{TiO}_{2}$, $\mathrm{P}_{2} \mathrm{O}_{5}$ and $\mathrm{MnO}$ are ranging from (1.01 to 0.68 wt. $\%),(0.49$ to 0.36 wt. $\%$ ) and (0.26 to $0.18 w t . \%)$ with the average weight percent of $(0.79 \mathrm{wt} . \%)$, $(0.44 \mathrm{wt} . \%)$ and $(0.22 \mathrm{wt} . \%)$ are can be seen as small amount of concentration. High concentration of $\mathrm{SiO}_{2}$ and $\mathrm{Al}_{2} \mathrm{O}_{3}$ are contributed by clay minerals such as illite. The clay minerals originated from the hydrolysis of plagioclase in the volcanic rocks.

\subsection{Geochemical fraction of lead}

The geochemical fraction of lead $(\mathrm{Pb})$ in exchangeable fraction is ranging from 0.18 to 2.83 ppm with an average concentration of $0.61 \mathrm{ppm}$ $(0.59 \%)$, in carbonate fraction is ranging from 0.43 to $2.91 \mathrm{ppm}$ with an average value of 1.08 ppm $(1.10 \%)$, in amorphous Fe Oxide fraction is ranging from 41.09 to $105.25 \mathrm{ppm}$ with the average of $68.99 \mathrm{ppm}(73.38 \%)$, in crystalline Fe Oxide fraction is ranging from 11.06 to $20.96 \mathrm{ppm}$ with an average concentration of $14.99 \mathrm{ppm}$ $(16.65 \%)$, in organic fraction is ranging from 1.06 to $2.15 \mathrm{ppm}$ with an average of $1.39 \mathrm{ppm}$ $(1.55 \%)$, and in residual fraction is ranging from 3.51 to $7.86 \mathrm{ppm}$ with an average of $5.72 \mathrm{ppm}$ $(6.73 \%)$. The value of lead concentration in geochemical fraction and their percentages of geochemical fraction are shown in Figures 2 and 3 .

Results of sequential extraction showed that $\mathrm{Pb}$ were concentrated mainly in amorphous $\mathrm{Fe}$ oxide in the soil profile with average of $73.38 \%$. It was followed by crystalline iron oxide with the average of $16.65 \%$. Metals associated with oxide (both amorphous and crystalline) minerals were likely to be released in reducing condition (Sharmin et al., 2010). The exchangeable fraction can be seen as negligible amount with average of $0.42 \%$ and small amount of carbonate fraction $1.04 \%$ are occurred in the unsaturated soil.

Musta et al., 2008, mention that the concentration of $\mathrm{Fe}_{2} \mathrm{O}_{3}$ in soil samples indicates the presence of iron oxides as adsorbent material in 

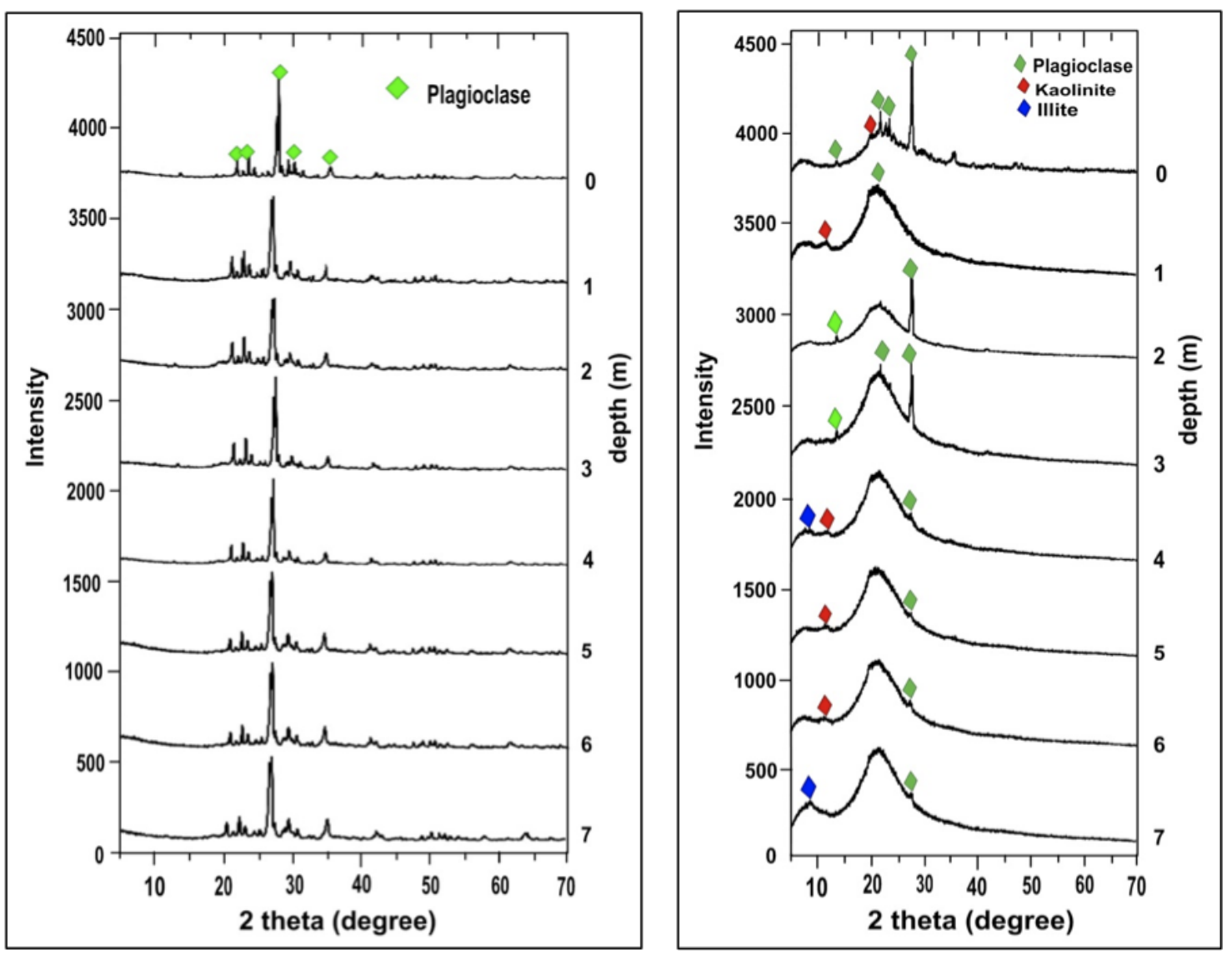

Figure 1: XRD pattern of unsaturated soil in (a) bulk sample, (b) clay fraction

Table 1: Chemical composition of soil samples.

\begin{tabular}{cccc}
\hline Chemical composition (wt.\%) & Minimum & Maximum & Average \\
\hline $\mathrm{SiO}_{2}$ & 51.1 & 58.5 & 56.64 \\
$\mathrm{Al}_{2} \mathrm{O}_{3}$ & 17 & 21.2 & 19.64 \\
$\mathrm{Fe}_{2} \mathrm{O}_{3}$ & 6.39 & 9.66 & 7.75 \\
$\mathrm{CaO}$ & 4.69 & 10.6 & 6.18 \\
$\mathrm{Na}_{2} \mathrm{O}$ & 2.34 & 3.22 & 2.63 \\
$\mathrm{~K}_{2} \mathrm{O}$ & 1.45 & 2.13 & 1.66 \\
$\mathrm{MgO}$ & 0.92 & 1.63 & 1.22 \\
$\mathrm{TiO}_{2}$ & 0.68 & 1.01 & 0.79 \\
$\mathrm{P}_{2} \mathrm{O}_{5}$ & 0.36 & 0.49 & 0.44 \\
$\mathrm{MnO}$ & 0.18 & 0.26 & 0.22 \\
\hline
\end{tabular}




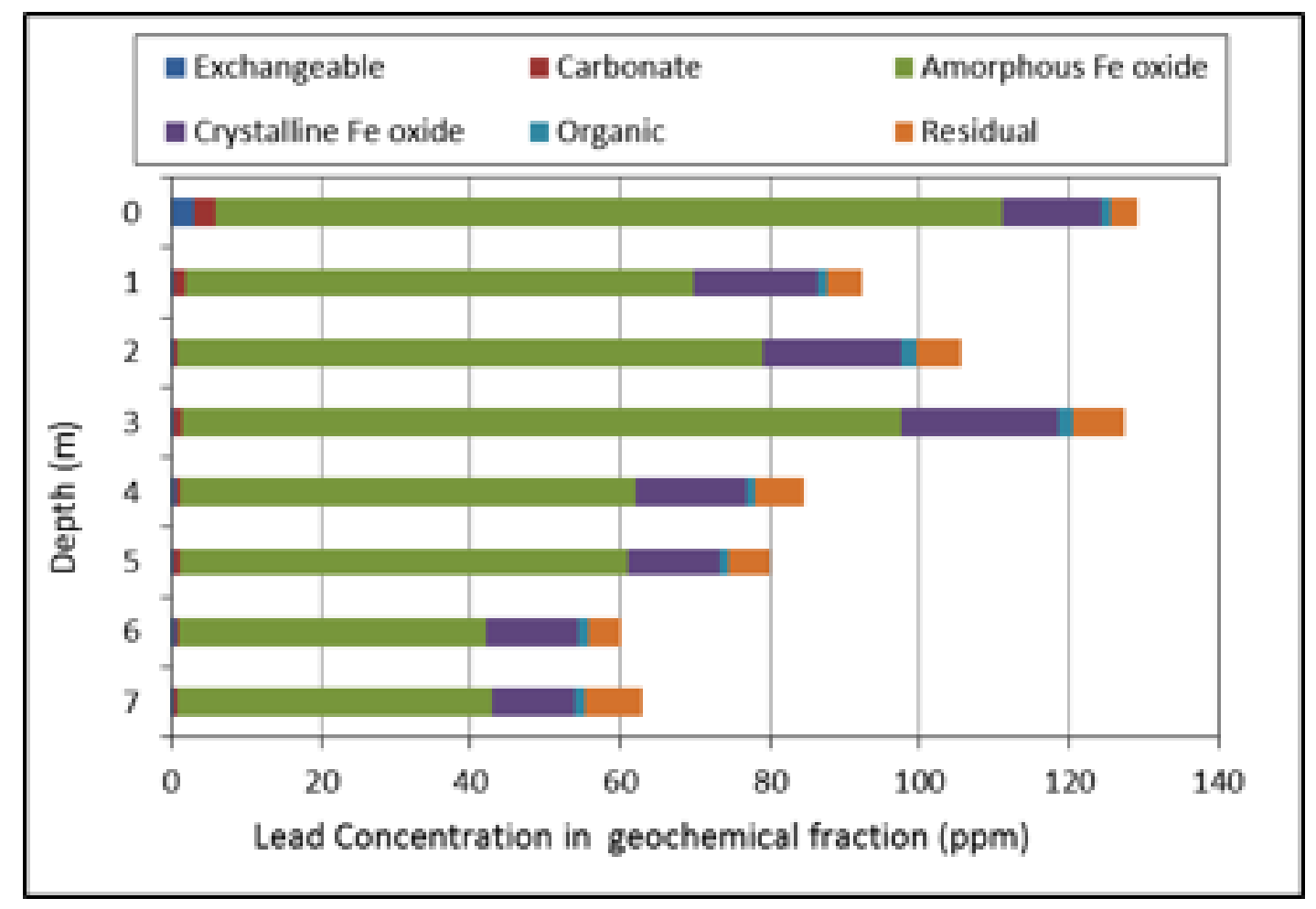

Figure 2: Geochemical fraction of $\mathrm{Pb}$ in soil samples.

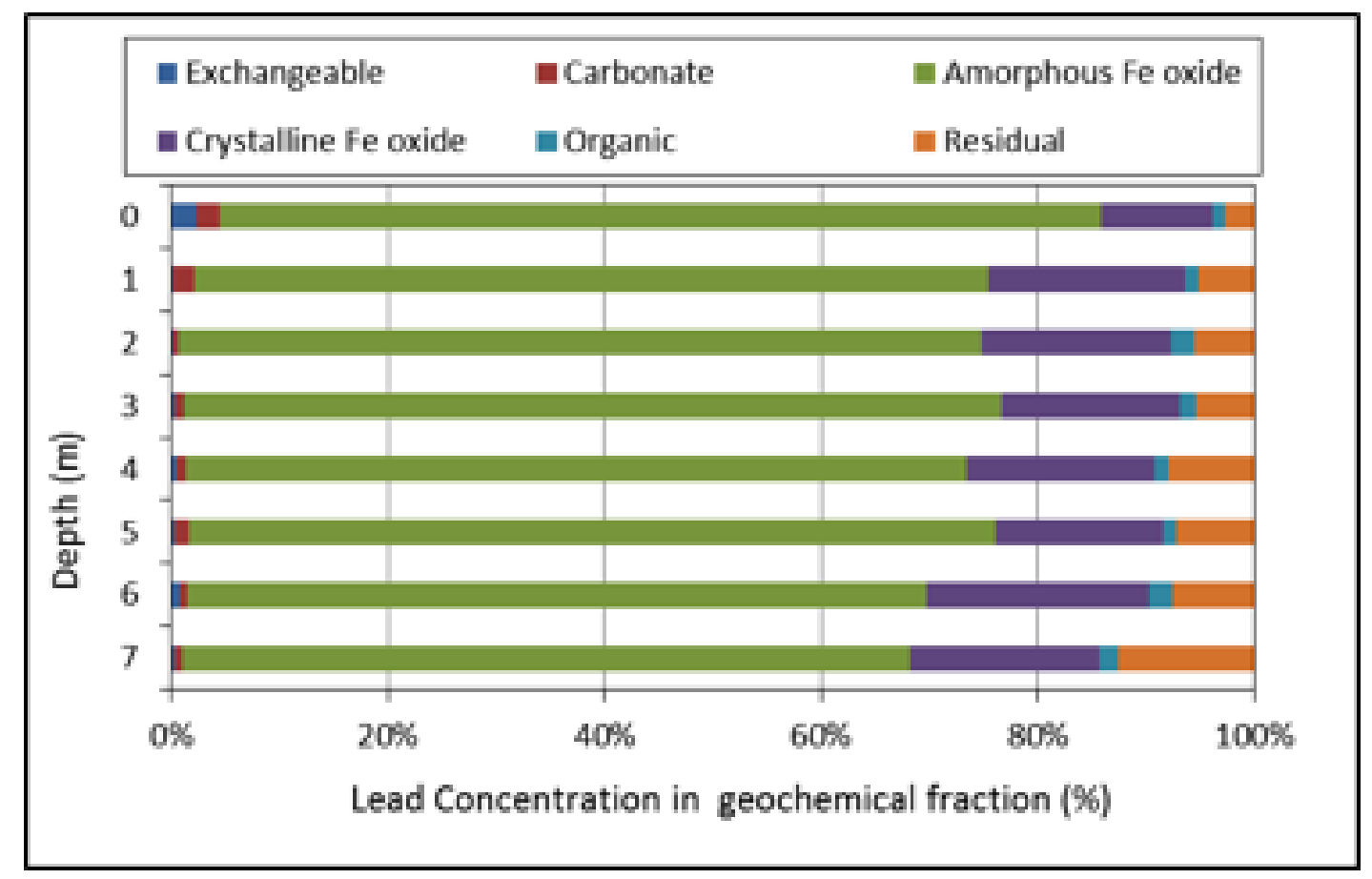

Figure 3: Geochemical fraction of $\mathrm{Pb}(\%)$ in soil samples. 
soil. The result of sequential extraction on this research agree with this statement as $\mathrm{Pb}$ content that bound to amorphous Fe oxide fraction are showing positive correlation with the percent of iron oxide in the soil/sediment sample (Figure 4).

\subsection{Mobility of lead}

The determination of mobility of metals $(\mathrm{Pb})$ in unsaturated soil may also be assessed on the basis of absolute and relative content of fractions weakly bound to soil components. The relative index of metal of metal mobility was calculated as mobility factor (MF) on the basis of the following equation (Kabala and Singh, 2001):

$$
M F=\frac{\left(F_{1}+F_{2}\right)}{\left(F_{1}+F_{2}+F_{3}+F_{4}+F_{5}+F_{6}\right.} \times 100
$$

Where:

$F_{1}=$ Exchangable fraction

$F_{2}=$ Carbonate fraction

$F_{3}=$ Amorphous Fe Oxide fraction

$F_{4}=$ Crystalline Fe Oxide fraction

$F_{5}=$ Organic fraction

$F_{6}=$ Residual fraction

The above index describes the potential mobility and it is the ratio of proportion of mobile $\left(F_{1}+F_{2}\right)$ to the total sum of all fractions. The MF gave the value in the range from 0.4 to 3.3 $\%$ for $\mathrm{Pb}$. The mobility of $\mathrm{Pb}$ in unsaturated soil of the study area indicates that they are likely have higher mobility on the surface soil and describes more available for plant and animal than the deeper part in the study environment. The relatively higher mobility of $\mathrm{Pb}$ on the surface soil seemed to be related to the pollution due to atmospheric deposition especially from traffic emission of vehicle in urban environment (Figure 5). Mobility of $\mathrm{Pb}$ at deeper soil/sediment show relatively lower mobility than soil in the surface area. The lower mobility of lead in deeper soil/sediment means that the probability of lead release to groundwater is also low.

\subsection{Bioavailability of lead}

Metals in non-residual fraction that include from exchange to crystalline Fe oxide which are likely to be bioavailability than metals associated with residual fraction (Oluwatosin et al., 2008). In the present study, the percentage of the non-residual forms of heavy metal are sum of the first five fractions $\left(F_{1}, F_{2}, F_{3}, F_{4}\right.$ and $\left.F_{5}\right)$ and non-available form of the heavy metal was consider as residual fraction $\left(F_{6}\right)$, see Figure 6 . Figure 6 shows that most of fractions of all the investigated heavy metals $(\mathrm{Pb})$ were found in non-residual (available) form with 88 to $97 \%$ with mean value of $94 \%$ and residual (available) form from 3 to $12 \%$ with the mean of $7 \%$.

A significant percentage of $\mathrm{Pb}$ was associated with non-residual fractions could be considered as potential available fractions means that $\mathrm{Pb}$ is readily available for plant uptakes and bioaccumulation and could be environmental risks (Jimoh et al., 2013). Furthermore, Honglei et al. (2008) mentioned that the present of more than $50 \%$ of $\mathrm{Pb}$ associated with non-residual fraction of unsaturated soil has indicated the influence of anthropogenic activities and $\mathrm{Pb}$ has the potential bioavailability.

The dissolution and consequently the mobility and bioavailability of metals are controlled by organic matter and oxides that act as principal adsorbents and this can prevent excessive mobilization of heavy metals (Oluwatosin et al., 2008). Beside, due to less concentration of $\mathrm{Pb}$ in exchangeable and carbonate fraction, $\mathrm{Pb}$ is not readily available for biological uptake and easily released to the environment and $\mathrm{Pb}$ that is adsorbed by amorphous Fe oxide in soil commonly have poor mobility and bioavailability (Violante et al., 2010).

As shown in Figure 6, the distribution of $\mathrm{Pb}$ in non-residual (available) fraction generally decreased with depth. But in contrast, the distribution of residual fraction is increasing with depth of the unsaturated soil in the study area. This fact reveals that $\mathrm{Pb}$ can be more favorable bio-available on the surface part of the study area. The fact that amorphous Fe oxide fraction is highest among the non-residual fraction in the study area, it can act as main adsorbents in the study area and can prevent the mobilization and bioavailability of $\mathrm{Pb}$ in the normal $\mathrm{pH}$-alkaline condition. But in reducing environment, $\mathrm{Pb}$ associated with oxide (both amor- 


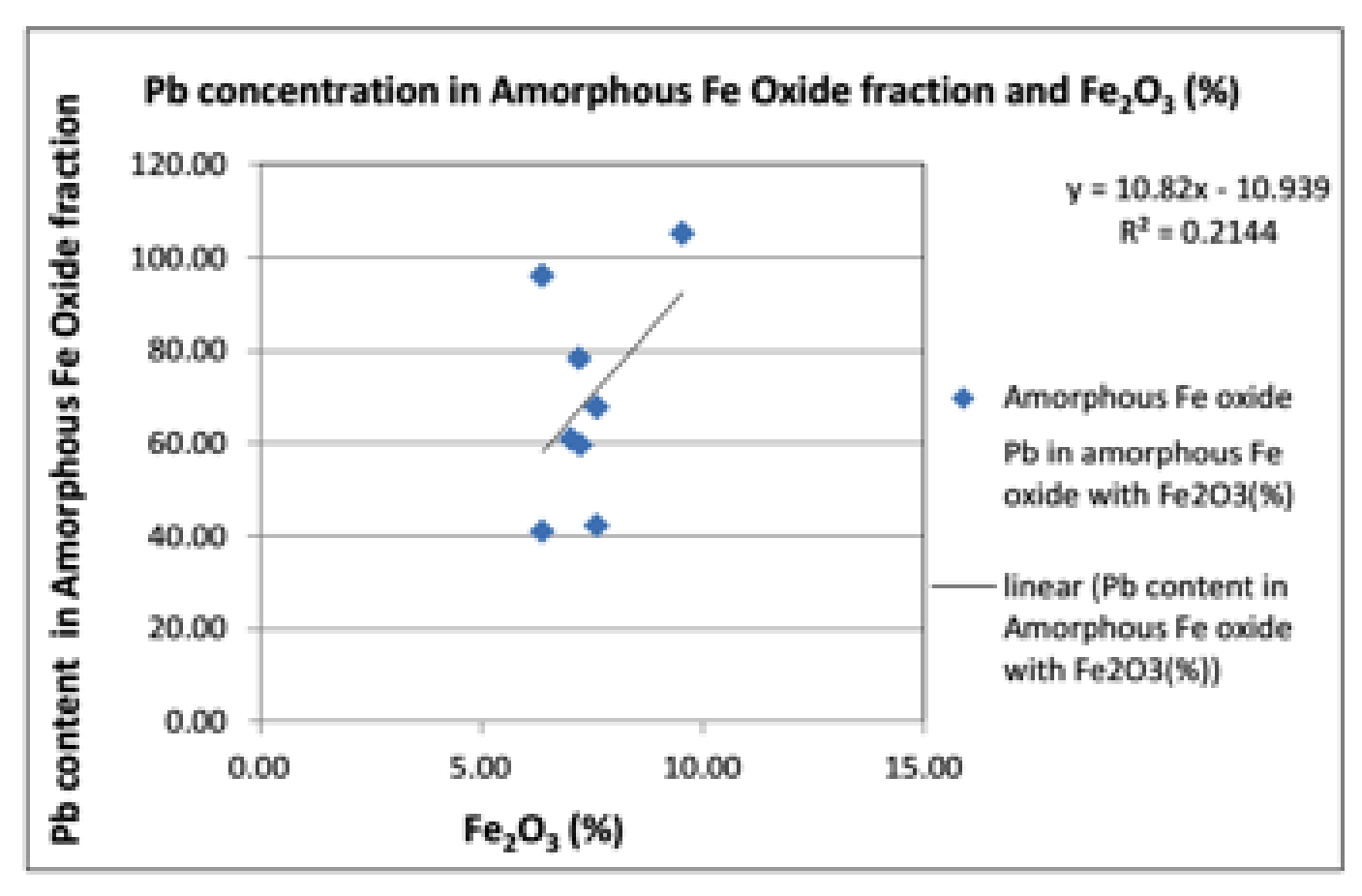

Figure 4: Correlation of $\mathrm{Fe} 2 \mathrm{O} 3(\%)$ and $\mathrm{Pb}$ in amorphous iron oxide fraction.

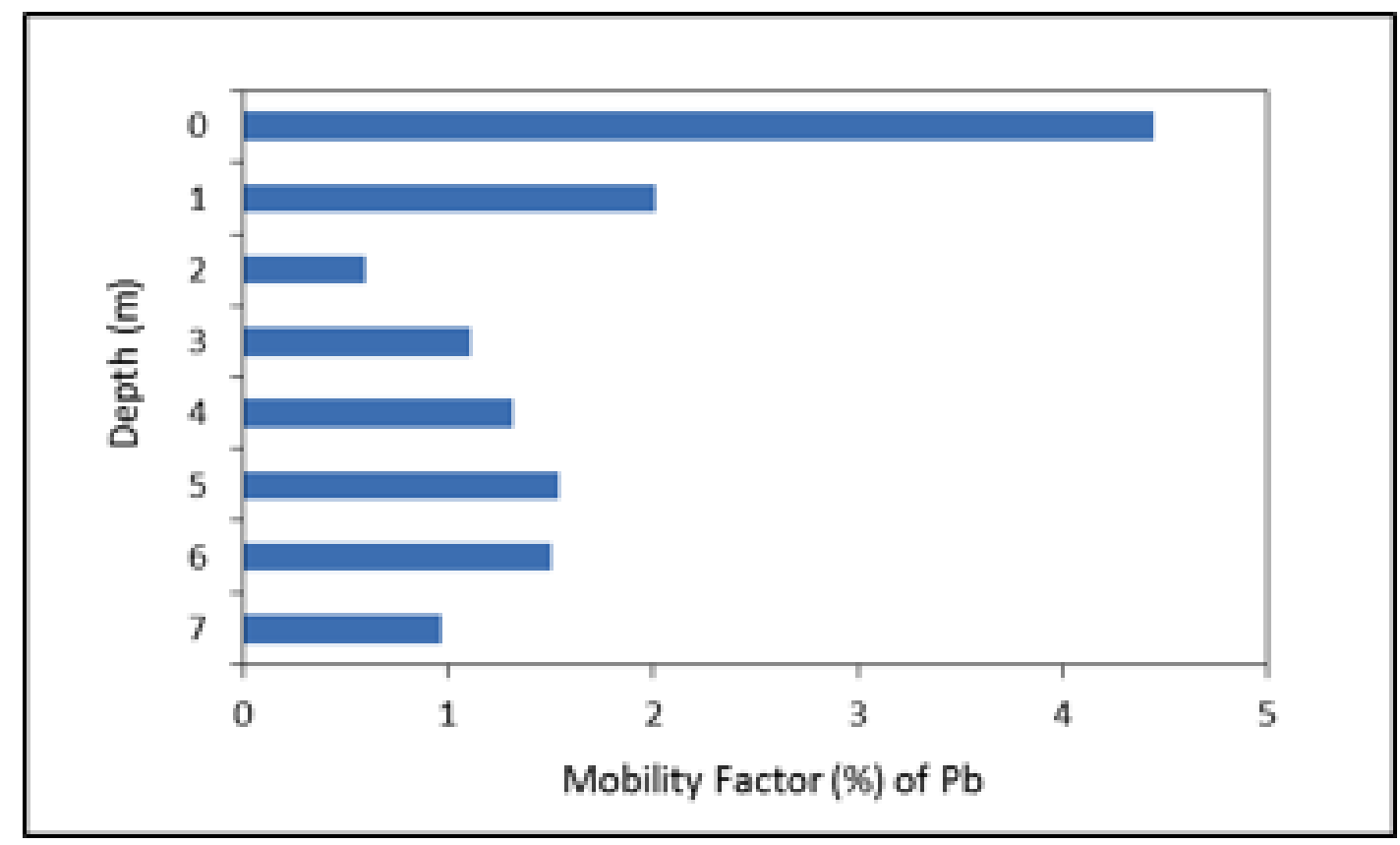

Figure 5: Mobility Factor of $\mathrm{Pb}$ in soil samples. 


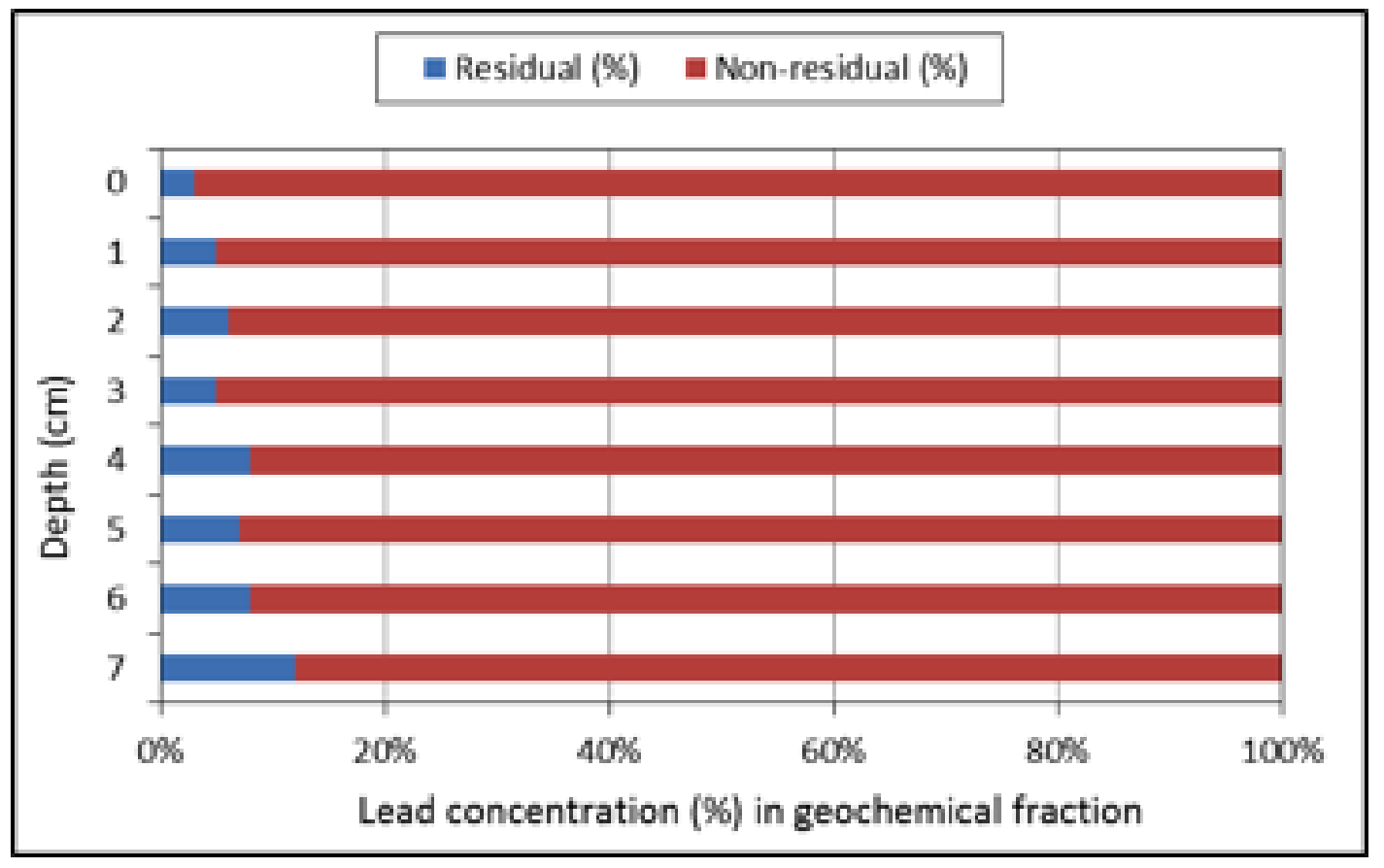

Figure 6: Non-residual and Residual concentration of $\mathrm{Pb}$ in soil samples.

phous and crystalline) minerals can be released to the environment (Sharmin et al., 2010).

In order to quantify the bio-availability of $\mathrm{Pb}$ in the study area, an assessment of risk to determine the availability of $\mathrm{Pb}$ in soil is conducted. This assessment called as Risk Assessment Code by applying a scale to the percentage of heavy metals in the exchangeable and carbonate fractions (Al-Robai, 2013). Exchangeable and carbonate bound metals are weakly bound to sediment components and may be considered more mobile and dangerous than other fraction. The risk assessment code indicates the sediment which can release heavy metal in exchangeable and carbonate fractions of the total concentration $<1$ (No risk) will be considered safe for the environment, 1-10 (Low risk), 11-30 (Medium risk), 31-50 (high risk), $>50$ (very high risk), and can easily enter the food chain (Sharmin et al., 2010). Using this $\mathrm{RAC}$ method, the $\mathrm{Pb}$ in unsaturated zone in the study area is classify into low risk zone (Figure 7). Therefore, it can be concluded that $\mathrm{Pb}$ contamination in soil of the study area is poorly bio-available. Even there is a low risk level of $\mathrm{Pb}$ in the unsaturated soil in the study area, it should be considered due to its negative impact for the human health in the future.

\section{Conclusion}

Results of sequential extraction showed that $\mathrm{Pb}$ in the unsaturated soil of Yogyakarta City were concentrated mainly in amorphous Fe oxide $(73.38 \%)$, crystalline iron oxide $(16.65 \%)$, and the rest amount distributed to exhangeable, carbonate, organic and residual fraction. The distribution of $\mathrm{Pb}$ in the various fractions confirms their difference in bioavailability and mobility. Although $\mathrm{Pb}$ concentration is high in non-residual fraction, amorphous Fe oxide can act also as main adsorbents and control the excessive mobilization of $\mathrm{Pb}$ in the unsaturated soil in the study area. The index of mobility factor show relatively high value on the surface soil can indicate that $\mathrm{Pb}$ can be potentially bio-available in this study area and the common source may be comes from the atmospheric emission. Last but not least, it can be also concluded that in the study area, $\mathrm{Pb}$ is in low risk condition due to its poor mobility and bioavailability. But concern on lead contamination should be considered because if the con- 


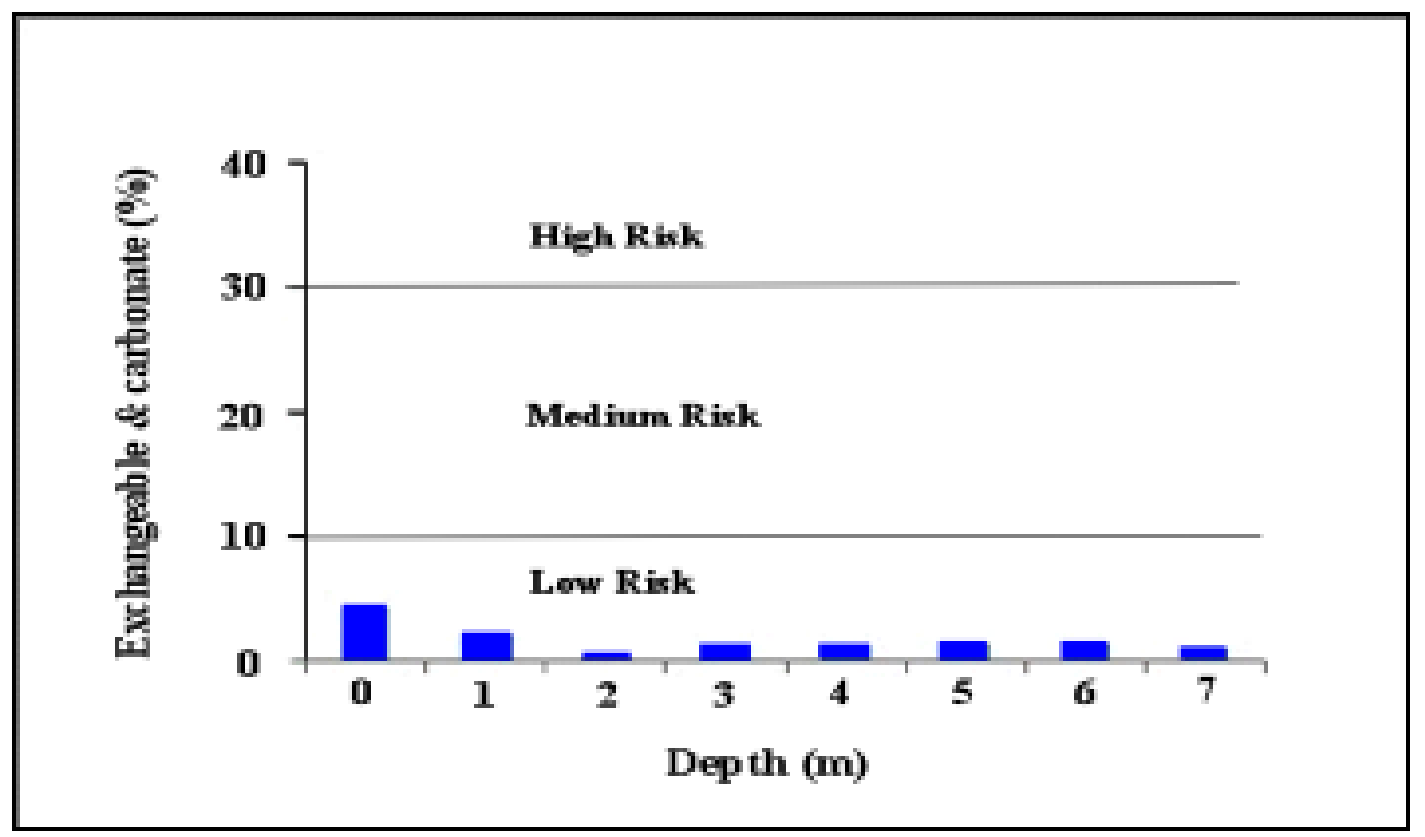

Figure 7: Risk Assessment Code of $\mathrm{Pb}$ in unsaturated soil.

centration of $\mathrm{Pb}$ is enriched over the adsorption capacity of iron oxide, it can easily release to the environment and can impact to human in the future.

\section{Acknowledgement}

Authors would like to thank the ASEAN University Network Southeast Asian Engineering Education Development Network (AUN/SEED-Net) program under the Japanese International Cooperation Agency contribution (JICA) and Center for Engineering Education Development (CEED), Hokkaido University for financial support academic contribution to this research.

\section{References}

Alloway, B.J. (2013) Heavy Metals in Soils: Trace Metals and Metalloids in soils and their Bioavailability, 3Ed, Springer, UK.

Al-Robai, H.A.H. (2013) Determination some heavy metals in sediments of Shatt AlHillriver by using modified single chemical fractionation technique, Journal of Babylon University, Pure and Applied Sciences, Vol. 21, No. 8, pp. 42-50.
Baiquni, M. (1994) Household Income and Decentralized Urban Infrastructure A Case Study of the Integrated Urban Infrastructure Development Programme -Yogyakarta Urban Development Project. Thesis (Master), Institute of Social Studies, Netherlands.

Budianta, W. (2012) Lead contamination in soil of Yogyakarta city, Indonesia, J. SE AsianAppl. Geol., Vol. 4, No. 2, pp. 9098.

Bradl, B.H. (2005) Heavy Metals in the Environment, Elsevier Ltd, ISBN: 0-12, 088381-3.

Herath, H. M. D. V., Pitawala, H.M.T.G.A., Gunathilake, J. and Dalugoda, T.Y.S. (2013) Heavy metal contamination in road deposited sediments in Colombo urban area. Proceedings to 29thTechnical Sessions of Geological Society of Sri Lanka, pp. 127-130.

Honglei, L., Liqing, L., Chengqing, Y., and Baoquing, S. (2008) Fraction distribution and riskassessment of heavy metals in sediments of Moshi lake, Journal of Environmental Sciences, Vol. 20, pp. 390-397.

Jimoh, W.L.O. and Sabo, Y. (2013) Sequential analysis of metals in municipal dumpsite composts of Kano metropolis, Nigeria, Bayero journal of Pure and Applied Sciences,Vol. 6, No. 1, pp. 87-91. 
Kabala, C. and Singh, B.R. (2001) Fractionation and mobility of copper, lead, and zinc insoil profiles in the vicinity of a copper smelter, J. Environ. Qual. No. 30, pp. 485-492.

Kanmani, S. and Gandhimathi, R. (2012) Assessment of Heavy metal contamination in soildue to leachate migration from an open dumping site, Applied Water Science, No. 3:193-205.

Karnawati, D., Pramumijoyo, S. and Hendrayana, H. (2006) Geology of Yogyakarta, Java: thedynamic volcanic arc city, The Geological Society of London, IAEG, No. 363, pp. 1-7.

Kumar, B., Kumar, S., Mishra, M., Singh, S.K., Prakash, D., Sharma, C. S. and Mukherjee, D.P. (2011) Geochemical fractionation of some heavy metals in soils in the vicinity of sukinda mining area, Orissa", Advances in Applied Science Research, Vol. 2, No. 5, pp. 263-272.

Manta, S. D., Angelone, M., Bellanca, A., Neri, R. and Sprovieria, M. (2002) Heavy metals inurban soils: A case study from the city of Palermo (Sicily), Italy, Sci.Env. Elsevier Science, No. 300, pp. 229-243.

Moore, F., Forghani, G. and Qishlaqi, A. (2009) Assessment of heavy metal contamination inwater and surface sediments of the Maharlu Saline lake, SW Iran, Journal of Science \& Technology, Transaction A, Vol. 33, No.1, pp. 43-55.

Musta, B., Fitria, H.W.S.E. and Tahir, S. (2008) Geochemical characterization of volcanic soils form Tawau, Sabah, Bulletin of the Ge- ological Society of Malaysia, Vol. 54, pp. 33-36.

Oluwatosin, G.A., Adeyolanu, O.D., Dauda, T.O. and Akinbola, G.E. (2008) Levels andgeochemical fractions of $\mathrm{Cd}, \mathrm{Pb}$ and $\mathrm{Zn}$ in valley bottom soils of some urban cities in southwestern Nigeria, African Journal of Biotechnology, Vol. 7, No. 19, pp. 3455-3465.

Putra, D.P.E. (2007) The Impact of Urbanization of Groundwater Quality - A Case Study in Yogyakarta City - Indonesia, Mitteilungen zur Ingeniuergeologie und Hydrogeologie, Heft 96, 148 S, Herausgegeben Vom (Lehrstuhl) fuer Ingenieurgeologie und Hydrogeologie, University Prof. Dr. Azzam, RWTH, Aachen, Germany.

Sharmin, S.H.M., Zakir, H.M. and Shikazono, N. (2010) Fractionation profile andmobility pattern of trace metals in sediments of Nomi River, Tokyo, Japan, Journal of Soil Science and Environmental Management Vol. 1, No. 1, pp. 001-014.

Tessier, A., Campbell, P.G.C. and Bisson, M. (1979) Sequential extraction procedure forthe speciation of particulate trace metals, Analytical Chemistry, Vol. 5, pp. 844-851.

Violante, A., Cozzolino, V., Perelomov, L., Caporale, A.G. and Pigna, M. (2010) Mobilityand bioavailability of heavy metals and metalloids in soil environments, J. Soil. Sci. Plant Nutr. Vol. 10, No. 3, pp. 268-292.

Wilopo, W., Haryono, S. N., Putra, D. P. E., Warmada, I. W. and Hirajima, T. (2010) Copper $\left(\mathrm{Cu}^{2+}\right)$ from water using natural zeolite from Gedangsari, Gunungkidul, Yogyakarta", J. SE Asian Appl. Geol., Vol. 2, No. 2, pp. 117120. 